\section{England in a Miniature in Mike Leigh's "The Short and Curlies"}

Working on The Short and Curlies (1987) was a breakthrough in Mike Leigh's career. After his successful and promising debut Bleak Moments (1971) the director felt the need to continue working in the film industry, but did not know where he should direct his career to. He spent a few next years working in the theatre and television. Throughout 1986 he was traveling and taking care of his sons. As he admits, he doubted whether he would ever work in the film industry again. He was a 43-year-old man, who believed that it was too late for another film debut. And then, as Leigh recalls, David Rose from Channel 4 contacted him and proposed that Leigh make a short film that would be a part of a series aired in the UK. Rose was so impressed with Leigh's film that he decided to give the whole series the title The Short and Curlies (Leigh has referred to this idea as ridiculous).[1] This almost eighteen-minute film meant to Leigh a return to work and the beginning of a new stage in his career.

It is noteworthy that all the themes which Mike Leigh developed in his subsequent films, appeared in The Short and Curlies. His films are known for having kept the same tone and having played out the same melody for years. This opinion can be easily turned into the accusation of being "boring" but Leigh turns it to his favour. His films are not boring. Monotony would mean a constant and repetitive playing out the same scheme. One could want to discover a pattern reoccurring in Leigh's films, however in vain, because under the pattern there are always characters and personalities, alive and changing. The miniature situations calmly observed in The Short and Curlies in static camera takes are the best proof. It is the way of telling a story that is the most fascinating and inviting to subtly yet completely enter the world of the characters.

Mike Leigh comments on the way he collects materials for his films in a very simple way:

I have my own aerials. I travel on a bus, come by to a pub for a drink, I read the newspapers. I'm nothing of an artist closed in an ivory tower. I'm firmly anchored in the mundane, real word. Both at the beginning of my career in the theatre and later when I made films for television, I always listened carefully to what was happening in my street. ... I'm not one of those intellectual filmmakers. My interests now are focused on family matters, work, unemployment, parents, children, sex, health... in other
Images

vol. X/no.19

Poznań 2012

ISSN 1731-450X
England

in a Miniature

[1] A. Raphael (ed.), Mike Leigh on Mike Leigh,

London 2008, pp. 183-184. 
words: life! Because of my age, I found my way to cinema in the period of the explosion of the New Wave, but, funnily enough, those directors didn't influence me. I consider Jean Renoir to be my only master. I admire his intelligence, humanism, and his ability to grasp what is unique. Renoir is my roots and my role model.[2]

This ordinary, everyday observation gave rise to the plot of The Short and Curlies, revolving around a love affair of Joy (Sylvestra Le Touzel), a young woman working at a chemist's and Clive (David Thewlis), a man who communicates with her only by means of his humourless jokes. Another story in the film is a complicated relationship of an eccentric hairdresser Betty (Alison Steadman), who is more interested in the life of the pharmacist than in the life of her own daughter Charlene (Wendy Nottingham). The story is told in a series of short scenes and ideally matches the English expression "to get/have someone by the short and curlies", which means "to control someone, to make someone be in a situation with no way out". So it is only seemingly all about new hairstyles of Joy (hair can also be "short and curly"), but in fact it is, which is characteristic of Mike Leigh's later work, a story about being entangled in relationships with other people (often your family). What is interesting, the pessimism (all the time balancing between tears and laughter), which was present in Leigh's early work, with time becomes more and more optimistic. In such films as Secrets and Lies or All or Nothing, despite numerous twists, the finale will bring a cleansing conversation and promise a bright future. Leigh did not give this chance to the characters of The Short and Curlies.

Short scenes from the life of the English in The Short and Curlies can be seen in each scene of the film. From details such as a street with a perfectly straight terrace of houses with small gardens to social questions that are constant in the British culture. As Ewa Mazierska says: "Mike Leigh was once called the painter of miniatures - his films and TV productions for which he is equally praised and admired, concentrate on life of «small people with small gardens»." [3]

The director's vision meets here with the idea that has been paramount to contemporary British filmmakers. The realism of the British street in Leigh's films has a double role: it perceptively comments on the current events and at the same time it shows a great deal of psychological insight which makes it possible to enter the world of the characters. However, there is no intrusion into the psyche of the characters in the form of internal monologues. They are described by means of observation and their social interactions. It should be stressed, however, that in spite of the fact that we look at Leigh's films from the perspective of social questions, the director denies that his cinema is social cinema:

[2] Tropiciel prawdy, the interview with Mike Leigh made by Michel Rebichon for Studio magazine 1996, issue 114, ed. M. Oleksiewicz, „Kino” 1997, issue 4, p. 51. [3] E. Mazierska, Z czułością, „Kino” 1997, issue 3, p. 37. 
... Cinema is the tool of propaganda. Hitler was well aware of it. So I'm not going to try to look like a committed director, I just want the audience to discover the feelings, emotions of the film characters and, through their stories, learn to better understand others. I'd rather say that I do a social criticism by means of observational cinema, without being pompous or ostentatious.[4]

His words, obviously with some fake modesty, express the attitude that reveals a social bent. Leigh is right when he refuses to be given a tag of a committed artist, but he admits that he does social criticism. It becomes the element which gives his films an authentic dimension. Ewa Mazierska, when writing about Secret and Lies, highlights the fact that this is because they touch on the social issues, Leigh's film are so real.

\begin{abstract}
However, in Leigh films one does not sense platitude or fakeness. I believe this is partly because the author is sensitive to details - the dialogues and the décor, or convincing actors' play (most of characters are played by permanent Leigh's collaborators: Timothy Spall, Phyllis Logan, Claire Rushbrook); partly it is because of the sole shape of the presented reality. What I mean is that in the contemporary Britain governed by the Tories the social boundaries have become ever tighter; there is more of conformism and identifying oneself with the values and way of thinking characteristic of one's own social class. One might say that in Britain reality has reached, or rather lowered to, the stereotype."[5]
\end{abstract}

Leigh's social commitment is also expressed in the cult of work, which becomes the paramount element of the miniatures he presents. In The Short and Curlies we get to know the two main female characters at work - at a hairdresser's and at a chemist's. The director shows ordinary modest people whose lives are important and valuable, because they have been sanctified by work. Leigh tries to emphasise the fact that ordinary people are no different than those who have succeeded. However, he is not interested in showing and diagnosing the existence in poverty. In this sense he is not a socially committed artist. For him it is crucial to look at the world of people who, in spite of the fact that they live on the lowest social level, experience the same problems as others. One of these problems is, naturally, the lack of communication with another human being. In this sense, the poverty of characters means that they are also mentally poor. They do not build normal, healthy relationships with others, because they are too upset and too tired of the futility of their daily grind. It can be clearly seen in the tired, slouched body posture of Betty and in the poor décor in the The Short and Curlies characters' homes. Hopelessness and helplessness gag the characters and let them communicate only by means of clichés (Clive's jokes) and mumbled monologues (Betty's chatter). In a review of Secret and Lies, Ewa Mazierska writes: 
The most important issue is the lack of communication. It is worth noticing that Leigh dealt with this problem before. Characters sitting at café tables unable to utter a single complete sentence, or chattering at the parties in a way that embarrasses both their interlocutors and themselves, were abundant in Bleak Moments, High Hopes and Abigail Party. Probably no other contemporary director has proved it that subtle intellectuals and well born people do not have a monopoly for existential problems, neuroses, alienation or inhibitions in communication - office workers, small business owners or factory workers can also suffer from them.[6]

England in a miniature presented in Leigh's films relate to the frequently discussed reference to the soap opera genre, which is subtly suggested by Mazierska in the review mentioned above:

[Leigh - A.S.] in different ways refers to the earlier films: Life is Sweet, High Hopes or Bleak Moments. Like in those films, he draws heavily upon the means that are associated with television. Similarly, in the centre of attention of the director is a family, or rather families - Leigh explores each of them and conducts detailed comparative studies.[7]

Indeed, Leigh's cinema uses the rules of television, but its reference to the genre cinema can be analysed even deeper - as aware arguing with the rules. According to Charles Altman, an expert on genre cinema, it is a ritual that makes repetition, and repetition exists so that the ritual can exist. Genre cinema was built on the basis of repetition, that is why the viewer can recognize the "other same". "Both in the inner-textual as intertextual aspect, the genre cinema use the same material". [8] This is what Leigh makes reference to, he chooses a known material, but for a completely different purpose than genre cinema-makers.

In Leigh's cinema the scheme described by Altman is the reference to a soap opera, in which a viewer accepts the world created by a director, because the viewer has seen such solutions in a thousand of other productions that built their power on being repetitive and predictable. However, Mike Leigh never sees his characters in genre dualism, but in each one he finds goodness and hope for a change. There is no soap opera, artificial division between the good and the wicked who should be punished according to the old scheme. There are real people suffering and fighting with their pain. That is why it turns out that even though they are closed in static takes with the British street in the background, they do not have a lot in common with the characters of EastEnders or Coronation Street.

Family under Magnifying Glass
As early as in the first scenes of The Short and Curlies featuring Betty and Charlene it can be seen that their relationship is a complicated one. The first conversation shows that the daughter is constantly displeased and withdrawn because of the offensive behaviour of the
[6] Ibidem, p. 37.

[7] Ibidem.
[8] Ch.F. Altman, Towards a Theory of Genre Film, Polish transl. of A. Helman, „Kino” 1987, issue 6, p. 21. 
mother. The mother is one of Mike Leigh's eccentric characters who are an explosive mixture of humour and undiagnosed insanity (such characters as Cynthia from Secrets and Lies, Poppy from Happy-GoLucky, or Mary from Another Year are each a masterpiece). The interactions of the women in the atmosphere of tension and silence of the daughter are contrasted with those in which Betty has a light-hearted banter with Joy.

The eccentric mother and the withdrawn daughter could become the characters who drive the plot in a soap opera world. Each conversation of Betty and Charlene results in inevitable failure. The lack of communication is exposed by the final scene in which the audience can clearly see that Charlene is heavily pregnant, but her mother is completely unaware of it and focused on choosing a new haircut for Joy.

In the final scene of Secrets and Lies (the best-known and most awarded of Leigh's films) one of the characters says the significant line about family relationships: "We're all in pain! Why can't we share our pain?".[9] This quote is not only an excellent comment on the situation in which the characters end up, but it also aptly sums up Mike Leigh's creative thought. His previous characters, most notably those from The Short and Curlies asked the same questions. But in the film from 1987 Leigh did not give them an optimistic answer. Many years later when asked about the further story of Joy and Clive, he said with irony that their relationship would probably last, but it shouldn't, because what kept them close together was a mere façade of jokes and conventions. [10] The scene in which Clive humiliates Joy right after their first intimate contact complements Leigh's words.

An equally bitter diagnosis could also be given to the relation of Betty and Charlene, who, although related, live next to each other. In Secrets and Lies the situation, also tragic, will turn out reverse. Here, slowly tightening family bonds lead to the optimistic finale in which, despite the previous dramas, the family becomes the source of new and unique strength. Only through relationship with others can one be able to rebuild a stable and harmonious world. The same theme will appear in the film All or Nothing which seems to be a natural continuation of Secret and Lies.[11]

Both in The Short and Curlies, and in the other mentioned films Leigh manages to do something that only the greatest manage to do. The genius of this director can be seen in his creation of reality which

[9] Quotation from Secrets and Lies.

[10] A. Raphael (ed.), op. cit., p. 187.

[11] It is worth noticing that in the 1980's Mike Leigh became a father of two sons. Even though the author of the present article does not believe in the autobiographical aspect of his stories, and will always support the idea of reading films as work independent from experiences and declarations of their makers, it can- not be ignored that it was in the late 1980's that the director's films become more family-oriented and this feature has become a constant element of his work (The Short and Curlies, High Hopes, Life is Sweet, Secrets and Lies, All or Nothing, Another Year). Also noticed by: R. Carney, L. Quart, The films of Mike Leigh. Embracing the world, Cambridge 2000, p. 274. 
evoke both desperation and laughter. This laughter through tears not only makes it possible to release the tension built up by the development of a plot, but also to relate to the world on the screen. On the rules of projection-identification we penetrate the reality that could be our own. The director leads the viewer through the life of the characters, thanks to which one can see what is an everyday share of each person. Sometimes we burst into laughter, sometimes we cannot hold the tears coming to our eyes. Leigh on different reactions of people to Secrets and Lies:

... I am surprised at these reactions, people laugh and cry during the same scenes! There is a scene in which at a meeting with her black daughter in a café a mother reminds herself that she had slept with a black man. When shooting this scene, we thought that it was very dramatic. None of us had imagined that during this long (ten minutes!) shot anyone would laugh at this confession, but in Cannes people did laugh. I was surprised, but at the same time flattered that I am able to evoke such different emotions. I am afraid of films which don't give the viewer a choice, thrusting arbitrary emotions upon him. Cinema is a living matter".[12]

But it is hard to avoid the conclusion that Leigh's films as such are balancing on the verge of these two most extreme emotions. In The Short and Curlies we can see Charlene's tragedy - lonely, closed in her shell and dominated by her mother, but at the same time we are unable to unequivocally reject the attitude of the mother, whom we accept with her idiosyncrasies, nosiness and loquacity. This character was based on the heroine of the Tokyo Story directed by Yasujirō Ozu, regarded by Leigh to be an unsurpassed film-making master.

Despite all the prejudice, it is impossible not to like Betty. The way Alison Steadman plays this role remains in memory. She gives eccentric Betty the voice which balances between tears and laughter. She is able to discharge even the most bleak and the saddest moments thanks to her out-of-the-ordinary personality (similarly to Brenda Blethyn in Secrets and Lies).

Close Circle of Friends
When commenting on the issue of realism, Leigh says that art cannot be a real life, because it has to be organised in a certain way, it needs to be distilled. There is no place for coincidence, because it is based on a concrete plan and idea.[13] To make things even more complicated, the director believes that only actors can play real people. He never chooses to work with amateurs (Ken Loach does), because they would never be able to act authentically. So he chooses professionals whom he knows well and with whom he works for many months to reach a perfect result. And this result is nothing less than a sphere that is the closest to our reality. Leigh relies on balancing between the perfection in taking care of details, and improvisation. 
The actors can afford it, because they do not play a particular role, they rather become a character created by the director in the first draft of the script. As Leigh emphasizes, only thanks to this can one reach something that becomes real feelings and emotions.[14]

Working with actors begins many months before the planned filming and consists in talking and trying to get into the role. Thanks to this an actor who appears on the set can start working easily. What is interesting, Leigh does not allow actors to meet beforehand, their interaction takes place only on the set. He says:

For me the behaviour of the characters, their reactions are the heart of the narration. Before filming I meet with each of my actors individually and I try hard not to let them contact one another. When they are finally on the set, I encourage them to improvise, to propose something of their own. I can continue writing my scripts on this basis. We shoot the film and, and when there is nothing more to shoot, we use the time for rehearsals and further improvisations. I think it is a good method of showing the truth about characters, their relationships, and the strength of their emotions. It is all way easier to me, because I have my technical crew, with whom I have worked for a long time and who got used to my constant search for truthfulness.[15]

Thanks to this actors who become characters are forced to react in a way that we know from everyday life. Therefore an actor is not an actor anymore, but becomes the character he plays. Leigh believes this is a necessary condition for truthfulness on the screen:

In my films I have always tried to find out who we really are. I have always made films about identity, respect and tenderness. I always try to reach as much truth and realism as possible, so that one can smell the skin of my characters and they become three-dimensional. My reasoning is very easy: the better the viewers get to know the characters, the better they understand them.[16]

Tadeusz Sobolewski adds his comment:

Mike Leigh's method of working with actors, based on many months of rehearsals, lets him construct the story based on people's faces. In Secrets and Lies the faces create a fascinating micro-drama, more interesting than the actual feature film plot. Leigh does not aim at exposing the characters. As a matter of fact, we are not dealing with satire, but with something to which the English criticism refers as tragicomic realism.[17]

Such roles become a real challenge, even for the best actors. Definitely this is why Leigh tends to return to the same collaborators. He knows, how much they are ready to sacrifice for a role, and he is well aware of their skills. It is also significant that the same faces that appear on another film set make a substitute for family and community. The

[14] Ibidem, p. 52.

[15] Tropiciel prawdy, op. cit., p. 50.

[16] Ibidem, pp. 50-51.
[17] T. Sobolewski, Amatorzy w teatrze życia, „Gazeta Wyborcza" 1997, issue 56, p. 15. 
director cares about such relations with collaborators most. Three actors with whom Leigh has collaborated permanently appeared in The Short and Curlies. The role of frustrated and eccentric Betty was played by Leigh's then-wife Alison Steadman, who also appeared in Hard Labour, Nuts in May, Abigail's Party, and, after 1987, in Life is Sweet, Topsy-Turvy and in a cameo in Secrets and Lies. Her best client, a young pharmacist Joy was played by Wendy Nottingham, whom we could later watch in Topsy-Turvy, Secrets and Lies and Vera Drake. The role of her silly boyfriend played David Thewlis, who also appeared later in Life is Sweet. But the key moment in his career was the role of Johnny in award-winning Naked. It should be remembered that Clive character from The Short and Curlies was in a way a sketch of Johnny. The protagonist of Naked will destroy all his relationships with women in the name of apparent freedom. His over intellectual gibberish (which in The Short and Curlies was a collection of jokes) will require to be fulfilled in life, the consequence of which is the final scene of the film in which Johnny leaves home in order to wander alone around the empty streets of London.

Leigh does not often work on a pre-written text. He prefers improvisation and the freedom of work. However, he always writes scripts for his films himself, and, which is not so common nowadays in the case of contemporary directors, he publishes them in print. It is definitely the echo of his theatrical experience which influenced his subsequent director's career and which is inherently connected with a written word. However, such a move also means that we can treat this text as a literary material. The first meeting with Leigh's scripts was a great surprise to the author of the present article. She had expected directions that would explain everything and a detailed description of each character, but what she received were simple dialogues, interrupted from time to time by information on the setting and characters' behaviour. The first disappointment that when reading Leigh's scripts soon turned into the idea that keeps the author convinced that this artist is extraordinary. Leigh did know that it would be impossible to give the readers a text full of deep and metaphorical analyses to which British cinema was resistant for so many years. The psychological depth resulting from the director's instructions would be a fake one. Both in the film and in the text everything happens among the real drama characters. The description and movingly rich portrait of characters is built by means of behavioural diagnoses and the delivered lines. At the same time the printed text shows us how precisely the dialogues are crafted, where there are no empty spaces, and there are multiple details which build the characters' portraits. A seemingly apsychological and behavioural description leads to the fuller presentation of the characters' depth. There are no random words, but there is consistency of the portrayal of people.

Mike Leigh's films have never been in the mainstream or entertained the masses. From the very beginning his cinema has required 
attention and patience. But he does not care about an intellectual dispute or receiving accolades for his experiments. On the contrary, he always chooses the ordinary and the mundane, which he tries to catch for a moment in his takes, because, as his characters say, life is too short. This cliché does not sound fake in the world created by Leigh, because the viewer deeply enters the reality of the characters and thanks to this is capable of understanding the micro drama he witnesses. In The Short and Curlies he proves that his mastery lies in the fact that he is not afraid of scenes that describe the reality in a documentary-like way. Mike Leigh knows that his strengths are well written dialogues and this extraordinary skill to become a fictional character possessed by the actors he chooses.

TV films and series:

Leigh's filmography

1964 The Wednesday Play

1970 Play for Today

1973 Hard Labour

1975 The Permissive Society

1976 Nuts in May

1976 Knock for Knock

1977 Kiss of Death

1977 Abigail's Party

1979 Who's Who

1980 Grown-Ups

1982 Home Sweet Home

1982 The Five Minutes Films

1984 Meantime

1985 Four Days in July

1987 The Short and Curlies

1992 A Sense of History

1992 Two Mikes Don't Make a Wright

Feature films:

1971 Bleak Moments

1988 High Hopes

1990 Life is Sweet

1993 Naked

1996 Secrets and Lies

1997 Career Girls

1999 Topsy-Turvy

2002 All or Nothing

2003 Cinema 16 (short story films)

2004 Vera Drake

2008 Happy-Go-Lucky

2010 Another Year 